\title{
血糖連続測定による経ロブドウ糖負荷試験の検討 一特に血糖曲線の型およびその多様性の成因の解析一
}

\author{
㴊上 正章 中野 博司 大庭 建三 妻鳥 昌平
}

\begin{abstract}
＜要 約 > 血糖連続測定下に $75 \mathrm{~g}$ 経ロブドウ糖負荷試験を行い，而楉能別に血糖曲線の型の特徵を明 らかにし，その血糖曲線の多様性の成因を主に年齢面およびインスリン分泌の面より検討した．対象は 21 歳から 87 歳までの非肥満男女合計70例である. 血糖曲線の型は大きく 1 峰型， 2 峰型および持続上昇 型の 3 つの型に分類された。

血糖曲線の型別頻度を耐糖能別にみると, 正常型群 $(n=15)$ は 1 峰型 $33.3 \% ， 2$ 峰型 $66.7 \%$ あり, 境界型群 $(\mathrm{n}=31)$ は 1 峰型 $67.7 \%, 2$ 峰型 $29.0 \%$, 持続上昇型 $3.2 \%, \mathrm{DM}_{1}$ 群（糖尿病型で空腹時血糖 值 $140 \mathrm{mg} / \mathrm{d} l$ 未満）（ $\mathrm{n}=15 ）$ は 1 峰型 $66.7 \%, 2$ 峰型 $13.3 \%$, 持続上昇型 $20.0 \%, \mathrm{DM}_{2}$ 群 $(140 \mathrm{mg} / \mathrm{d} l$ 以 上） $(\mathrm{n}=9)$ では 2 峰型は 1 例もなく, 1 峰型 $77.8 \%$, 持続上昇型が $22.2 \%$ であった. 2 峰型の頻度は正 常型群が他の群に比し有意に高率であった。また, 境界型群の 2 峰型の 9 例中 8 例は若壮年群（60歳末 満）であり， 1 峰型の頻度を年代別に比較すると老年群は 17 例中 15 例と, 若壮年群 14 例中 6 例に比し, 有意に高率であった.

$\mathrm{DM}_{2}$ 群を除外した症例について 1 峰型と 2 峰型の 2 群に分け比較すると, 頂値に到る時間および頂値 は 1 峰型群が 2 峰型群に比し有意に高值であり, 初期インスリン反応を示す各種指標も 1 峰型群が 2 峰 型群に比し有意に低值であったが，後期インスリン反応には差がなかった.

以上の結果は, 1 峰型と 2 峰型の血糖曲線の形成には初期のインスリン反応の差が大きな一次的要因 である可能性を示唆している。また，老年者の境界型のほとんどは，若壮年者の境界型と異なり初期の インスリン反応の低下を伴った 1 峰型であった.
\end{abstract}

Key words：経ロブドウ糖負荷試験，血糖曲線，インスリン反応，老年者

\section{緒言}

経ロブドウ糖負荷試験（以下 OGTT と略す）は耐糖 能の判定の簡便かつ信頼性の高い方法として現在広く 用いられているが122), 近年血糖の連続測定が容易とな り,この OGTT 時の血糖曲線は単一な型ではなく 様々な型を呈することが明らかにされている3 ${ }^{344}$. しか し，これまでの報告は，年齢面への配慮やこの血糖曲 線の多様性の成因や臨床的意義に関しての十分な検討 がなされていない。

本研究では, 血糖連続測定下に OGTT を行い, 而糖 能別に血糖曲線の型の特徵を明らかにし，同時にその 血糖曲線の多様性の成因を主に年齢面およびインスリ ン分泌の面より検討した。

\footnotetext{
M. Fuchigami, H. Nakano, K. Oba, S. Metori : 日本 医科大学老人科

受付日：1994。2.3，採用日：1994。4.6
}

\section{対象と方法}

対象は, 学生ボランティア10例を含む 21 歳から 87 歳 までの非肥満男女合計70例である，各種内分泌疾患， 高脂血症, 脳血管障害, 肝疾患, 膵疾患, 感染症およ び腎機能障害を有する者, 耐糖能に影響する諸種薬剤 服用者および消化管手術の既往例は除外した。

検査前日は禁酒, 午後 9 時以降は禁食とし, 当日は 午前 8 時30分より Glucose Monitor GM-1320 (京都第 一社製）を前腕肘静脈に装着し 2 分毎の血糖測定を開 始し, 同時に対側前腕静脈にも採血用の静脈カテーテ ルを留置した. Glucose Monitor GM-1320により測定 した負荷前血糖值の安定を確認した後, 午前 9 時にブ ドウ糖 $75 \mathrm{~g}(300 \mathrm{~m} l$ 溶液) を経口負荷し, 負荷後 3 時間 にわたり安静, 臥位にて血糖值の連続測定を行った。 対側前腕静脈からは負荷前, 負荷後 $2,4,6,8$, 10，14，18，20，30，60，90，120，180分に採血し血 清インスリン值（以下 IRI と略す）を測定した。また 
その一部について静脈血獎を用いてオートアナライ ザー法にて血糖值を測定した。

血糖曲線の型は以下の基準により 3 つの型に分類し た. 1 峰型は血糖値が負荷後持続的に上昇し，一定時 間後に頂值を迎えた後に漸次低下寸る型，2 峰型は負 荷後に血糖値が漸次上昇し第 1 の頂值を迎えた後に低 下し, 頂値の $15 \%$ 以上の低下を有意とした底値に達し た後, 底值の $15 \%$ 以上の上昇を有意とした第 2 の頂值 を形成するもの, 持続上昇型は負荷後 3 時間まで持続 的に上昇する型とした。

対象を, 日本糖尿病学会委員会勧告値 ${ }^{2}$ に従い耐糖 能別に正常型, 境界型及び糖尿病型に分類, さらに糖 尿病型は空腹時血糖値 $140 \mathrm{mg} / \mathrm{d} l$ 以上のものを $\mathrm{DM}_{2}$ 群, $140 \mathrm{mg} / \mathrm{d} l$ 末満のものを $\mathrm{DM}_{1}$ 群とし, 計 4 群に分 類した。また, 年代別に60歳以上を老年群, 60 歳未満 を若壮年群の 2 群に分類した。

負荷前から負荷後 180 分までの血糖曲線下の面積を 血糖総面積 $\left(\Sigma B S 180^{\prime}\right)$ とした。 1 峰型は頂值に, 2 峰 型は第 1 の頂值に到るまでの時間を頂値時間とした. インスリン反応を評価する目的で, 負荷前値と負荷後 30 分值の IRI 值の差と血糖值の差の比 ( $\Delta \mathrm{IRI}$ ) $\left.\triangle \mathrm{BS} 30^{\prime}\right)$ と負荷前より負荷後30分までのインスリンお よび血糖曲線下で囲まれる部分の面積比 (S IRI/S $\left.\mathrm{BS} 30^{\prime}\right)$ および負荷後30分から180分までのインスリン および血糖曲線下で囲まれる部分の面積比 (S IRI/S BS 30〜180'), 頂值時間までのインスリン曲線および 血糖曲線下の部分の面積比 (S IRI/S BS 1st Peak) および頂值時間の IRI 值と空腹時 IRI 值の差を頂值時 間で除したもの $(\Delta \mathrm{IRI} / \mathrm{min})$ を求めた. IRI は RIA2抗 体法, $\mathrm{HbA}_{1 \mathrm{c}}$ は HPLC 法を用いた。肥満度はBody
Mass Index $\left(\mathrm{kg} / \mathrm{m}^{2}\right)$ （以下 BMI と略す）を用い, 17.0 以上, 25.0 未満を非肥満とした。

統計は, 比率の検討は $\chi^{2}$ 検定, 平均值の差の検定は 2 群間の場合は Student t-test, 3 群以上の場合には一 元配置分散分析法を用い, 群間比較は Scheffe の方法 によった.また, 1 峰型と 2 峰型の各種指標の比較に ついては耐糖能の因子を考慮した二元配置分散分析法 を用いた．回帰直線は回帰の有意性が95\%以上の場合 に有意とした。

\section{成 績}

GM-1320で測定した血糖値と，同時採血し静脈血漿 オートアナライザー法で測定した血糖值との間には相 関係数 $\mathrm{r}=0.997$, 回㷌直線 $\mathrm{y}=1.00 \mathrm{X}+0.32(\mathrm{y}:$ 静脈

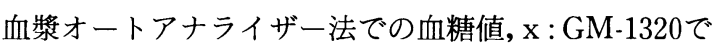
の血糖值, $\mathrm{n}=298, \mathrm{p}<0.001)$ と強い相関を得た。そ こで, 本研究では以下 GM-1320で測定した血糖値を用 い検討した。

表 1 に対象の背景因子を年代別, 耐糖能別に示した. 若壮年群および老年群のいずれも, 各耐糖能群間の平 均年齢, 男女比执よび平均 BMI に有意差はなかった。 平均 $\mathrm{HbA}_{1 \mathrm{c}}$ 値はいずれの群も耐糖能の低下とともに 有意に上昇した $(\mathrm{p}<0.001)$.

表 2 に耐糖能別の血糖曲線の型の頻度を, 図 1 に型 別の血糖およびインスリン曲線を例示した，全症例で みると 1 峰型の頻度は正常型群 $33.3 \%$ (15例中 5 例) と低率で, 境界型, $\mathrm{DM}_{1}$ および $\mathrm{DM}_{2}$ 群がそれぞれ $67.7 \%$ (31例中 21 例)， $66.7 \%$ (15例中 10 例)， $77.8 \%$ ( 9 例中 7 例) と高率の傾向がみられたが各耐糖能群間 に有意差はなかった $(p=0.08)$ 。一方, 2 峰型は正常

表 1 対象の背景因子

\begin{tabular}{|c|c|c|c|c|c|}
\hline 耐 糖 能 & 正常型 & 境界型 & $\mathrm{DM}_{1}$ 型 & $\mathrm{DM}_{2}$ 型 & \\
\hline 若壮年群 & & & & & \\
\hline 症例数 & 8 & 14 & 6 & 4 & \\
\hline 男／女 & $6 / 2$ & $12 / 2$ & $5 / 1$ & $2 / 2$ & \\
\hline 年齢（歳） & $34.0 \pm 14.8$ & $40.0 \pm 15.0$ & $52.5 \pm 2.1$ & $50.7 \pm 5.3$ & \\
\hline Body Mass Index $\left(\mathrm{kg} / \mathrm{m}^{2}\right)$ & $21.3 \pm 0.6$ & $21.6 \pm 1.4$ & $22.4 \pm 1.1$ & $20.8 \pm 1.6$ & \\
\hline $\mathrm{HbA}_{1 \mathrm{c}}(\%)$ & $5.6 \pm 0.4$ & $5.9 \pm 0.4$ & $7.3 \pm 0.8$ & $9.1 \pm 0.8$ & $\mathrm{p}<0.001$ \\
\hline 老年群 & & & & & \\
\hline 症例数 & 7 & 17 & 9 & 5 & \\
\hline 男／女 & $5 / 2$ & $9 / 8$ & $5 / 4$ & $3 / 2$ & \\
\hline 年齡 (歳) & $68.8 \pm 5.9$ & $72.5 \pm 6.2$ & $72.5 \pm 5.2$ & $67.6 \pm 4.4$ & \\
\hline Body Mass Index $\left(\mathrm{kg} / \mathrm{m}^{2}\right)$ & $20.7 \pm 1.4$ & $20.6 \pm 1.9$ & $21.6 \pm 1.3$ & $21.7 \pm 0.9$ & \\
\hline $\mathrm{HbA}_{1 \mathrm{c}}(\%)$ & $6.3 \pm 0.5$ & $6.4 \pm 0.7$ & $7.5 \pm 1.0$ & $9.0 \pm 0.9$ & $\mathrm{p}<0.001$ \\
\hline
\end{tabular}


1峰型，74歳，男性，境界型
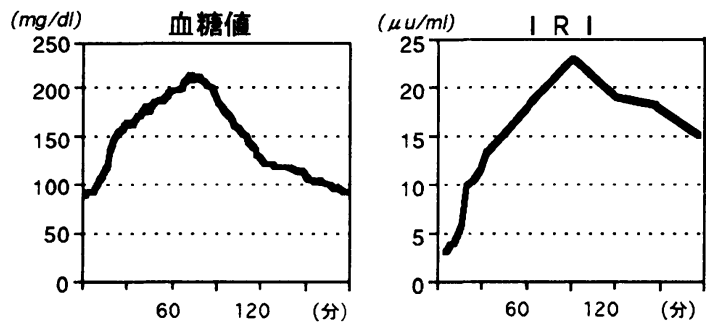

2峰型, 21歳, 男性, 境界型
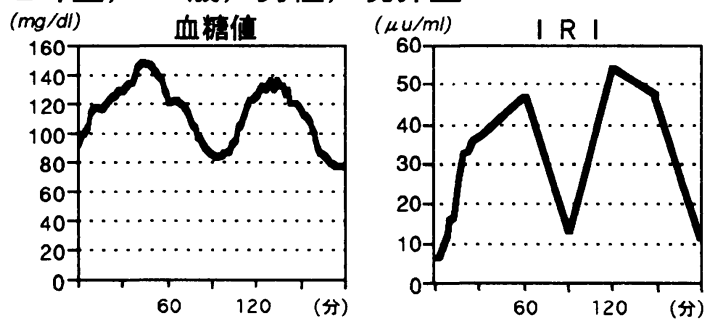

持続上型，67歳，男性，DM1型
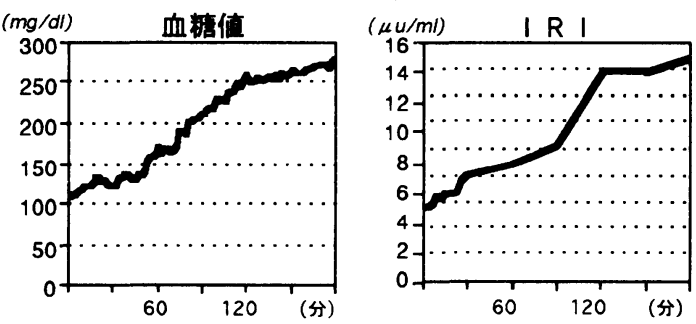

図 11 峰型, 2 峰型および持続上昇型の血糖および インスリン曲線の例示

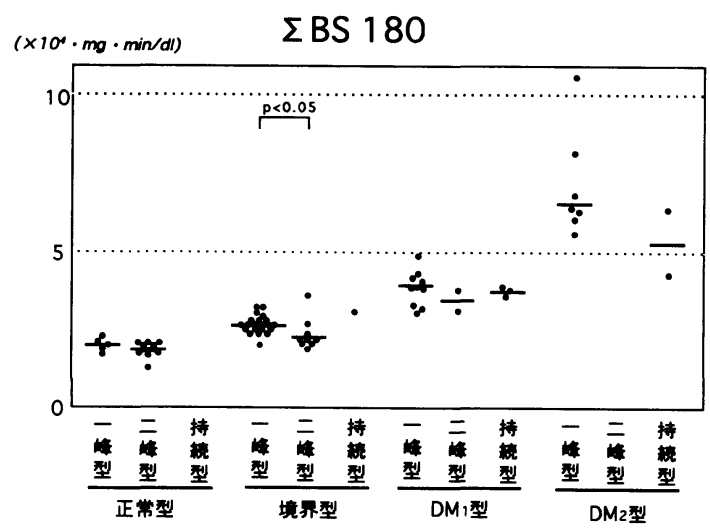

図 2 耐糖能別，血糖曲線の型別の $\Sigma B S 180^{\prime}$ 持続型：持続上昇型, - ; 平均値

型群が $66.7 \%$ （15例中10例）と最も高率で，ついで境 界型群 $29.0 \%$ (31例中 9 例)， $\mathrm{DM}_{1}$ 群 $13.3 \%$ (15例中 2
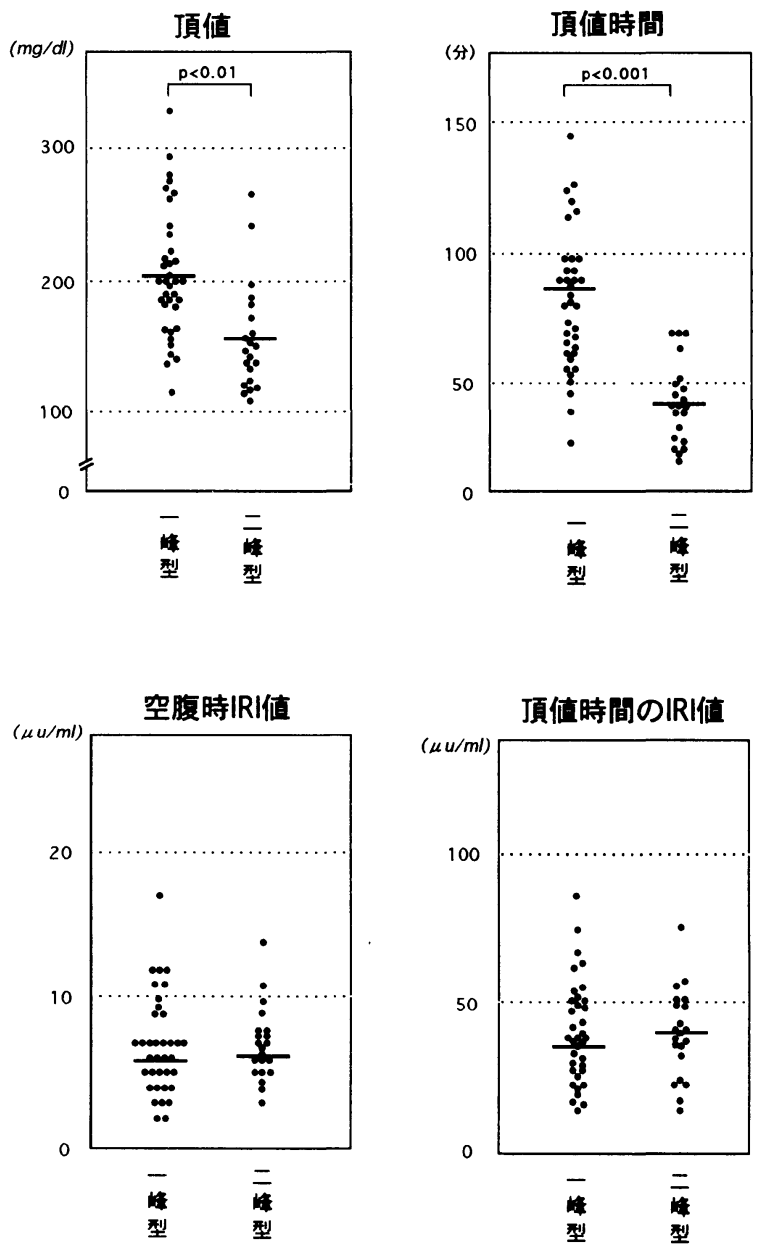

図 31 峰型と 2 峰型の頂値, 頂值時間, 空腹時 IRI 值および頂値時間の IRI 值の比較. - ; 平均值

例)， $\mathrm{DM}_{2}$ 群は 1 例もみられず耐糖能の低下とともに 有意に低率となった $(\mathrm{p}<0.01)$ 。持続上昇型は境界型 群 1 例, $\mathrm{DM}_{1}$ 群 3 例, $\mathrm{DM}_{2}$ 群 2 例の計 6 例であった。 これを年代別に比較すると, 境界型群の型別頻度に有 意差がみられ, 老年群17例中 15 例は 1 峰型であり, 若 壮年群14例中 6 例に比し， 1 峰型の頻度は有意に高率 であった $(\mathrm{p}<0.01)$.

血糖曲線の型別の $\Sigma$ BS180'を耐糖能別に比較した ものを図 2 に示した。 1 峰型群の $\Sigma B S 180^{\prime}$ は 2 峰型群 に比し正常型群, 境界型群および $\mathrm{DM}_{1}$ 群のいずれも高 值であったが，境界型群のみ有意であった $(\mathrm{p}<0.05)$. 持続上昇型群は, 境界型群の 1 例の值および $\mathrm{DM}_{1}$ 群の 3 例の平均はそれぞれ 1 峰型の平均値に近似してい た. 
表 2 耐糖能別の血糖曲線の型の頻度

\begin{tabular}{l|c|c|c|c|c|c|c|c}
\hline \multirow{2}{*}{ 耐糖能 } & \multicolumn{2}{|c|}{ 正常型 } & \multicolumn{2}{|c|}{ 境界型 } & \multicolumn{2}{c|}{$\mathrm{DM}_{1}$ 型 } & \multicolumn{2}{c}{$\mathrm{DM}_{2}$ 型 } \\
\cline { 2 - 8 } & 若壮年群 & 老年群 & 若壮年群 & 老年群 & 若壮年群 & 老年群 & 若壮年群 & 老年群 \\
\hline 症例数 & 8 & 7 & 14 & 17 & 6 & 9 & 4 & 5 \\
\hline 1 峰型 & 3 & 2 & 6 & 15 & 5 & 5 & 4 & 3 \\
2 峰型 & 5 & 5 & 8 & 1 & 0 & 2 & 0 & 0 \\
持続上昇型 & 0 & 0 & 0 & 1 & 1 & 2 & 0 & 2 \\
\hline
\end{tabular}
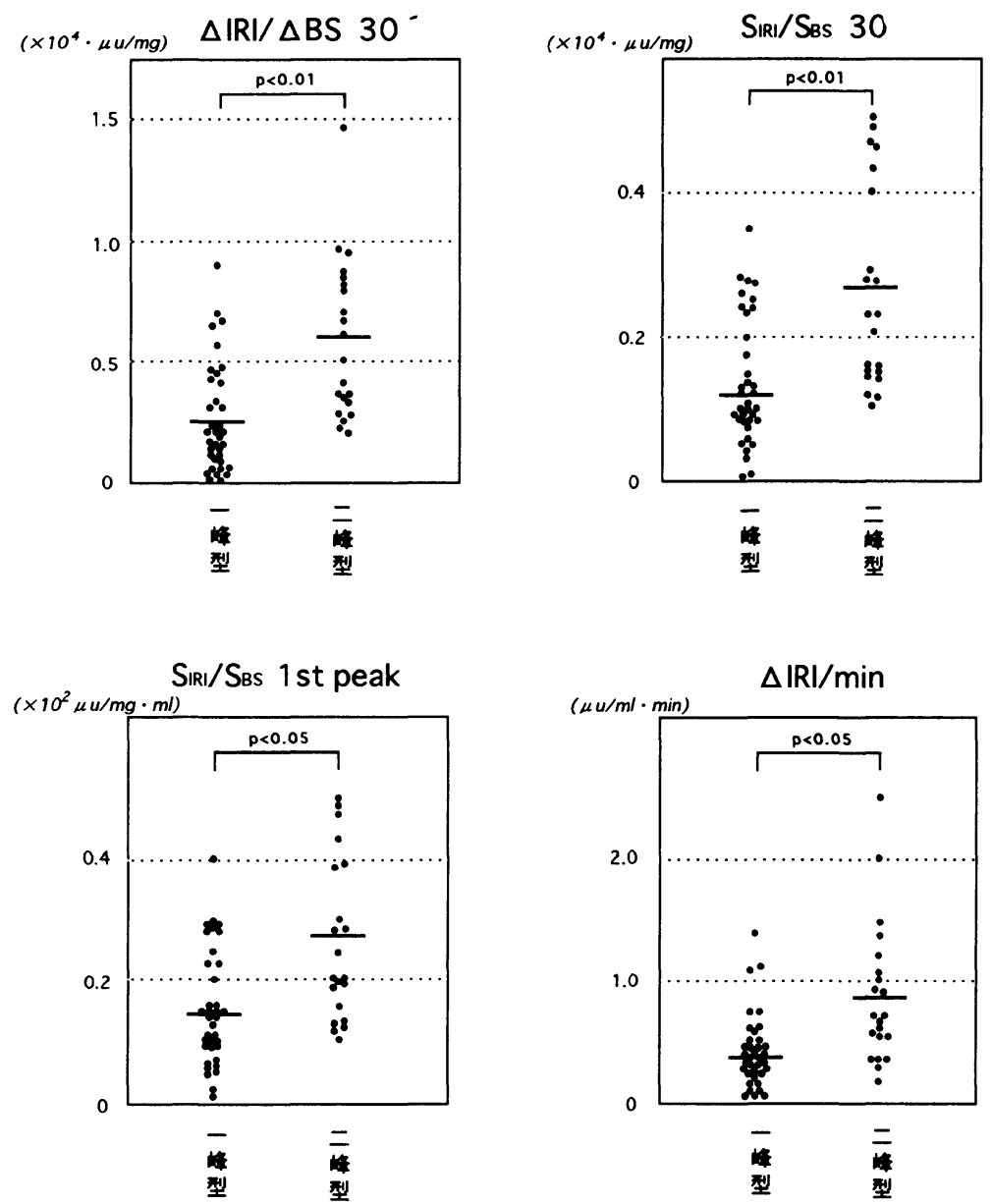

図 41 峰型と 2 峰型の $\Delta \mathrm{IRI} / \Delta \mathrm{BS} 30^{\prime}, \mathrm{S}$ IRI/S BS30', S IRI/S BS 1st peak およ び $\Delta \mathrm{IRI} / \mathrm{min}$ の比較. - ; 平均值

図 3 に $\mathrm{DM}_{2}$ 群を除外した症例を 1 峰型と 2 峰型の 2 群に分け, 2 群間の頂值, 頂值時間, 空腹時 IRI 值 および頂値時間の IRI 值を比較した成績を示した。平 均頂値および頂值時間は 1 峰型群が 2 峰型群に比し有 意に高值であった (各々 $\mathrm{p}<0.01, \mathrm{p}<0.001$ ). 平均空 腹時 IRI 值および頂值時間の IRI 值には両群間に差は
なかった。

図 4 に同様に 1 峰型群と 2 峰型群について平均 $\Delta \mathrm{IRI} / \triangle \mathrm{BS} 30^{\prime}$, S IRI/S BS30', S IRI/S BS 1st Peak および $\Delta \mathrm{IRI} / \mathrm{min}$ を比較した成績を示した。いずれの 指標も 1 峰型群が 2 峰型群に比し有意に低值であった (各々 $\mathrm{p}<0.01, \mathrm{p}<0.01, \mathrm{p}<0.05, \mathrm{p}<0.05)$ ．図には 
示さなかったが S IRI/S BS 30～180'値は両群間に差 はなかった。

\section{考案}

近年, 血糖持続測定装置が開発され OGTT 時の血 糖值の連続的変化を容易にとらえることが可能となつ た. 本研究で使用した Glucose Monitor GM-1320によ る血糖測定は正確度および安定性において良好な特性 が得られていることが報告されている5). 本成績でも 同時採血した静脈血漿オートアナライザー法による血 糖値とは $\mathrm{r}=0.997$ と極めて良好な相関が得られ，また その回帰式は $\mathrm{y}=1.00 \mathrm{x}+0.32$ と本装置における血糖 值は静脈血獎值とほほ同一とみなされる成績であっ た.

血糖連続測定による OGTT 時の血糖曲線の型別の 頻度を耐糖能別にみると, 正常型群では $1 / 3$ が 1 峰型, $2 / 3$ が 2 峰型であり, 2 峰型の頻度が他の耐糖能群に比 し有意に高率であった。境界型群になると 2 峰型が $1 /$ 3 と低率となり 1 峰型がその $2 / 3$ を占め, 1 例の持続上 昇型がみられた. $\mathrm{DM}_{1}$ 群では 2 峰型は 15 例中の 2 例と さらに低率となり $\mathrm{DM}_{2}$ 群では 1 例もなく, 糖尿病型の 両群の大部分が 1 峰型であった。また, $\mathrm{DM}_{1}$ および $\mathrm{DM}_{2}$ 群のいずれにも持続上昇型が約 2 割の頻度で認 められた。

原納ら ${ }^{3)}$ は，健常人および糖尿病外来受診者57例を 対象とし，その血糖曲線の型を山型， 2 峰性型，プラ トー型および上昇型の 4 型に分類し検討している. 山 型は本研究での 1 峰型, 2 峰性型は 2 峰型, プラトー 型および上昇型は持続上昇型に相当するものと考えら れる. 正常型群 12 例では， 5 例が山型， 7 例が 2 峰性 型で両型が混在しており, 本成績も同様であった。糖 尿病型群 28 例は山型, プラトー型がおのおの11例, 上 昇型が 6 例であり, 2 峰性型のものは 1 例もなかった. 本成績では $\mathrm{DM}_{1}$ 群に少数例ではあるが 2 峰性型がみ られたが糖尿病型例では 1 峰型と持続上昇型がほとん ぞを占め彼等の報告と同様であった。境界型群につい ては大きな差異がみられ, 原納らの境界型ないしは WHO 分類での IGT 群に属した16例は山型 8 例, プラ トー型 5 例, 上昇型 2 例で 2 峰性型は 1 例のみであり, 血糖曲線の型は糖尿病型に類似した特徵を有してい る.これに対し, 本成績では境界型の約 $1 / 3 に 2$ 峰型が みられ原納の成績よりも 2 峰型が明らかに高率であっ た.この差異の要因は不明であり, 今後検討すべき課 題と考えられるが, 我々は対象の年齢の差を大きな要
因の 1 つと考えた．本成績で境界型群31症例中 2 峰型 を呈した 9 例を年代別にみると, その内 8 例が若壮年 群であり，老年群は 1 例のみであった。原納ら成績で は対象の年齢の記載がないので比較できないが，森田 $ら^{4)}$ は24歳から35歳までの若年健常者19例について検 討し, 全例が 2 峰性を呈し, 本型が正常型群に特徵的 な型であると報告している。本研究で 2 峰型を呈した 境界型群 9 例中 5 例は 20 歳代前半の学生ボランティア であった。境界型の平均 $\Sigma$ BS180 の值は 2 峰型が 1 峰 型に比較すると有意に低值であったが，この傾向は正 常型群においても見られた。後述するインスリン反応 の結果や OGTT の従来から指摘されている再現性の 問題を考慮すると ${ }^{6)}$, これら境界型群の 2 峰型例の糖 代謝は正常型群に近い可能性が考えられる。一方，老 年群の境界型群のほとんどの症例は 1 峰型であり,こ の老年者における結果は原納らの成績と一致し，その 型は糖尿病型群に近似していた。加齢とともに耐糖能 が低下し，老年者に境界型に属するような軽度耐梼能 異常が高率にみられることはよく知られた事実であ り，その成因に関しては多くの加齢変化が複雑に関与 しているものと考えられている778).この加龄にともな う軽度耐糖能異常とインスリン非依存型糖尿病の病態 生理学的な変化にはいくつかの差異を指摘する報告も あるが9 ${ }^{911)}$ ，両者の代謝上の所見は極めて類似してお り判別が困難であるとされている ${ }^{12)}$. 老年群の境界型 にはこれらの加齡にともなう而糖能異常例が多く含ま れていることが 1 峰型が高率となった理由ではないか と考えられる。

ついで, 血糖曲線の多椂性の成因を検討する目的で, 症例の多かった 1 峰型と 2 峰型について, その差違を 主としてインスリン分泌の面より検討を行った。この 際, 2 峰型のみられなかった $\mathrm{DM}_{2}$ を除いた正常型, 境 界型および $\mathrm{DM}_{1}$ 群の 3 群について, その耐糖能の違い による影響を除外する目的で，型別と耐糖能別を 2 要 因とする二元配置分散分析法を行い, 両型の各種指標 を比較した。その結果，頂値および頂值時間は 1 峰型 が 2 峰型に比し有意に高値であり，1 峰型の糖処理能 は 2 峰型に比し低下している事が明らかとなった。同 様の事実は原納ら ${ }^{3)}$ も観察している。つぎに 1 峰型と 2 峰型をインスリン分泌の面よりみると, 平均空腹時 IRI 值および頂值時間の IRI 值には両群に差はなく IRI 值の絶対値では 1 峰型と 2 峰型との判別はし得な かった，従来より，負荷されたブドウ糖に対するイン スリン分泌能の良否の評価はブドウ糖負荷後の血中イ 
ンスリン上昇量を, 血糖值の上昇量で除したinsulinogenic index が優れた指標として評価されてい る.これには絶対値の差の比 ${ }^{13)}$ や, 面積の比 ${ }^{14)}$ が用いら れている，そこで，インスリン分必量をその時の血糖 值に対する比，すなわち相対的分泌量を示す平均 $\triangle \mathrm{IRI} / \triangle \mathrm{BS} 30^{\prime}$, S IRI/S BS30', S IRI/S BS 1st Peak および $\Delta \mathrm{IRI} / \mathrm{min}$ 值で検討を行ったところ，これらの いずれの指標も 1 峰型が 2 峰型に比し有意に低值で あった。一方, 後期のインスリン反応の指標である $\mathrm{S}$ IRI/S BS30〜180'值は両群間に差はなかった。この結 果は, 空腹時血糖値が $140 \mathrm{mg} / \mathrm{d} l$ 程度までの軽度の耐 糖能障害例の肝における糖産生が健常人と差がない事 実を考え併せると ${ }^{15)}$ ，ブドウ糖負荷に対する初期のイ ンスリン反応の差が血糖曲線の型に大きな影響を及ほ している可能性を示している.すなわち負荷されたブ ドウ糖に対する膵 $\mathrm{B}$ 細胞の反応性が良好な例が, 初期 における糖処理能力が高い為に, その頂値時間は短縮 し，同時に頂值は低下し， 2 峰型の血糖曲線を呈する のではないかと考えられた。

以上の結果は，ブドウ糖に対する初期のインスリン 反応が血糖曲線の形成にあたり大きな一次的要因であ る可能性を示唆するとともに, 血糖曲線の型が膵 B 細 胞機能を推定させる指標となりうる可能性をも示して いる. 今後この意義づけは多方面からの検討が必要と 考えられる．この点に関して初期インスリン分泌能の 低いものから将来高率に糖尿病に移行することが明ら かにされていることから ${ }^{16)}$, 今回の検討において特に 正常型群15例中の, 学生ボランティア 2 例を含む 5 例 の 1 峰型のもの, 境界型群では若壮年者に高率にみら れた 2 峰型のものおよび老年者の境界型群についての 今後の長期にわたる経年観察による糖尿病の発症率の 検討などが重要な課題と考えられる。

\section{文献}

1) WHO Expert Committee on Diabetes Mellitus. Second Report. Technical Report Series 646, WHO, Geneva, 1980.

2）小坂樹徳, 赤沼安夫, 後藤由夫, 羽倉稜子, 平田幸 正, 川手亮三, 葛谷 健, 三村悟郎, 中山秀隆, 坂 本信夫，繁田幸男：糖尿病の診断に関する委員会 報告. 糖尿病 $1982 ； 25: 859-866$.

3）原納 優, 鈴木正昭, 小杉圭右, 柏木厚典, 繁田幸 男, 竹内 誠：GTT の連続測定. 糖尿病 1982; $25: 37-40$.
4）森田須美香, 中田邦也, 石原一秀, 吉田泰昭, 土井 邦紘, 馬場茂明：経ロブドウ糖負荷試験時の血糖 連続測定による 2 峰性血糖曲線の意義について。 糖尿病 $1983 ; 26: 1041-1045$.

5）槙村博之, 北田勝久, 石井克彦, 松森康有, 吉岡正 子, 高嶋隼二, 松岡 瑛, 河井昭治, 岸本進一: 血 糖持続測定装置の開発と持性. 臨床検査機器・試薬 $1982 ; 5: 180-185$.

6) Kosaka K, Mizuno Y, Kuzuya T: Reproducibility of the oral glucose tolerance test and rice-meal test in the mild diabetics. Diabetes 1966 ; 15 : 901-904.

7) Davidson MD: The effect of aging on carbohydrate metabolism: A review of the English literature and a practical approach to the diagnosis of diabetes mellitus in the elderly. Metabolism 1979; 28: 688-705.

8) DeFronzo RA : Glucose intolerance and aging. Diabetes Care 1981 ; $4:$ 193-201.

9) Fraze E, Chiou Y-A, Chen Y-DI, Reaven GM : Age-related changes in postprandial plasma glucose, insulin, and free fatty acid concentrations in nondiabetic individuals. J Am Geriatr Soc $1987 ; 35: 224-228$.

10) McGuire EA, Tobin JD, Berman M, Andres R: Kinetics of native insulin in diabetic, obese, and aged men. Diabetes $1979 ; 28: 110-120$.

11) DeFronzo RA, Ferrannini E: Insulin resistance: A multifaceted syndrome responsible for NIDDM, obesity, hypertension, dyslipidemia, and atherosclerotic cardiovascular disease. Diabetes Care 1991 ; 14: 173-194.

12）井藤英喜：加秢と糖代謝. Geriat Med $1990 ； 28$ : $7-12$.

13) Kosaka K, Hagura R, Kuzuya T, Kuzuya N : Insulin secretory response of diabetics during the period of improvement of glucose tolerance to normal range. Diabetologia $1974 ; 10: 775$ -782 .

14) Seltzer HS, Allen $W$, Herron AL, Brennan MT : Insulin secretion in response to glycemic stimulus: Relation of delayed initial release to carbohydrate intolerance in mild diabetes mellitus. J Clin Invest $1967 ; 46: 323-335$.

15) DeFronzo RA, Ferrannini E, Simonson D : Fasting hyperglycemia in non-insulin- 
dependent diabetes mellitus: Contributions of excessive hepatic glucose production and impaired tissue glucose uptake. Metabolism $1989 ; 38: 387-395$.

16) Kadowaki $T$, Miyake $Y$, Hagura R, Akanuma
Y, Kajinuma H, Kuzuya N, Takaku F, Kosaka $\mathrm{K}$ : Risk factors for worsening to diabetes in subjects with impaired glucose tolerance. Diabetologia $1984 ; 26: 44-49$.

Abstract

\title{
Oral Glucose Tolerance Test Using a Continuous Blood Sampling Technique for Analysis of the Blood Glucose Curve
}

\author{
Masaaki Fuchigami, Hiroshi Nakano, Kenzo Oba and Shouhei Metori
}

Blood glucose levels were continuously monitored in 70 subjects during a $75 \mathrm{~g}$ orla glucose tolerance test (OGTT). Subjects were divided into normal $(\mathrm{N}=15)$, borderline $(\mathrm{N}=31)$, diabetes with fasting glucose levels below $140 \mathrm{mg} / \mathrm{dl}\left(\mathrm{DM}_{1}\right)(\mathrm{N}=15)$ and diabetes with levels above $140 \mathrm{mg} / \mathrm{dl}\left(\mathrm{DM}_{2}\right)(\mathrm{N}=9)$. Three patterns of blood glucose curves were observed in each subject group; domed, biphasic and upward. The frequency of blood glocose patterns in each class of glucose tolerance group was as follows: in the normal group; domed $33.3 \%$, biphasic $66.7 \%$; in the borderline group; domed $67.7 \%$, biphasic $29.0 \%$, upward $3.2 \%$; in the $\mathrm{DM}_{1}$ group; domed $66.7 \%$, biphasic $13.3 \%$, upward $20.0 \%$; in the $\mathrm{DM}_{2}$ group; domed $77.8 \%$, upward $22.2 \%$. The frequency of patients with a biphasic pattern was

The Division of Geriatric Medicine, Nippon Medical School significantly higher in the normal group than in the other groups. In the borderline group, almost all patients with a biphasic pattern were young or middle aged $(<60$ years old). When the patients with fasting glucose levels below $140 \mathrm{mg} / \mathrm{dl}$ were analyzed, the mean peak time and peak value of blood glucose levels were significantly higher in patients with domed patterns than those with biphasic patterns. Indices of early insulin response to glucose load were significantly lowre in patients with domed patterns than in those with a biphasic pattern. In conclusion, the pattern of the glucose curve in an OGTT is mainly dependent on the patient's early insulin reponse. Glucose intolerance with aging resembles diabetes from the standpoint of the pattern of glucose tolerance curves.

Key words: Oral glucose tolerance test, Blood glu. cose curve, Insulin response, Elderly

(Jpn J Geriat 1994; 31: 518-524.) 